\title{
Atomic s \\ Review: Elemental Analysis of Individual Fluid Inclusions by Laser Ablation-ICP-MS
}

\author{
Xian Lin, ${ }^{a}$ Wei Guo, ${ }^{* a}$ Lanlan Jin, ${ }^{a}$ and Shenghong $\mathrm{Hu}^{\mathrm{a}}$ \\ ${ }^{a}$ State Key Laboratory of Biogeology and Environmental Geology, China University of Geosciences, Wuhan, 430074, P. R. China
}

Received: Jan. 25, 2020; Revised: Feb. 16, 2020; Accepted: Feb. 20, 2020; Published: Feb. 25, 2020.

\begin{abstract}
Fluid inclusions are the most direct record of the chemical and physical properties of ancient fluids trapped deep in the Earth's crust and provide essential information about the geological formation of hydrothermal ore deposits. Laser ablation inductively coupled plasma mass spectrometry (LA-ICP-MS) has become a most powerful technique for the elemental analysis of individual fluid inclusions trapped within crystals of gangue as well as ore minerals. This review aims to summarize recent developments in elemental analysis of individual fluid inclusions by LA-ICP-MS and discusses the solutions for improving the success rate of ablation, accurate quantification, and selection of suitable fluid inclusions. Significant future progress can be achieved by developing a non-transparent ore mineral-hosted fluid inclusions analytical method using the combination of near-infrared light microscopy (NIR) and LA-ICP-MS, and further improving the detection limit by using high sensitive mass spectrometry and a fast extracting LA cell, accurate measurement of the internal standard element concentration, and development of the well-determined calibration materials and/or the fluid inclusion certified reference materials (CRMs).

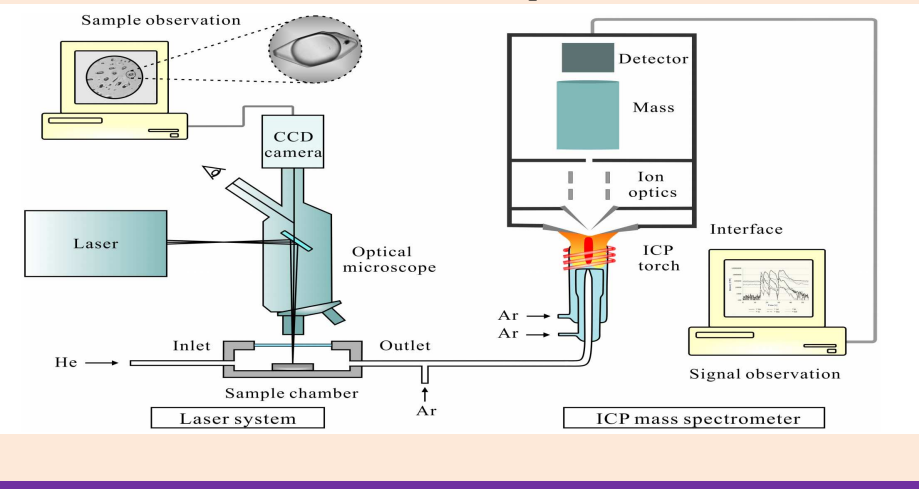

\section{INTRODUCTION}

Fluid inclusions are small droplets of fluid $(\sim 50 \mu \mathrm{m})$ trapped in natural minerals during their growth from hydrothermal solutions (primary inclusions) or during later deformation (secondary or pseudo-secondary inclusions). ${ }^{1}$ They are the most direct record of the chemical and physical properties of ancient fluids trapped deep in the Earth's crust and provide essential information about the geological formation of hydrothermal ore deposits. ${ }^{2-7}$ Elemental compositions of fluids provide key information to constraining fluid-mediated chemical cycling in the Earth. Element concentration averaged over many inclusions can be obtained by crush-leach analysis or bulk analysis of quartz containing fluid inclusions. ${ }^{8,9}$ However, these data only provide the composition of the mixture of various fluid stages present in the sample. Obviously, better sampling resolution is required to resolve different fluid stages trapped in a given sample in order to refine our understanding of fluid-mediated processes in the Earth.

Laser ablation inductively coupled plasma mass spectrometry (LA-ICP-MS) is regarded the most powerful technique for the elemental analysis of fluid inclusions for a large number of elements. ${ }^{10}$ The advantages of in-situ, timeliness, high spatial resolution, high sensitivity and precision, low detection limits, and a 
large dynamic line range have been widely investigated for the direct analysis of solid samples. ${ }^{11-15}$ Several reasons why LA-ICP-MS is currently the method of choice for fluid inclusion solute chemical and isotopic analysis: i) LA-ICP-MS analyzes the volume rather than the surface; hence, the entire fluid inclusion (i.e., gas, liquid, and crystals) content is available for analysis. However, other microbeam techniques (e.g., EPMA or SIMS) require solid material and/or have a slow "drilling rate". ${ }^{16}$ ii) LA-ICP-MS allows independent optimization of two fundamentally different processes: (a) sample liberation by laser ablation and (b) ion production, analyte filtering and signal recording in an ICP-MS. This dual optimization potential reduces matrix effects on signal quantification, which is an enormous advantage over most other in-situ analytical techniques (e.g., SIMS or LIBS) where ion production or light emission is directly related to sample ablation. ${ }^{10}$ Since the basic principles for LA-ICP-MS analysis of individual fluid inclusions have been pioneered by Günther et al., ${ }^{16}$ the LA-ICP-MS method was refined during the last decade by Günther et al., Audétat et al., Halter et al., Heinrich et al., Allan et al., and Pettke et al. ${ }^{10,17-26}$ In recent years, some difficulties (i.e., low success rate of ablation, accurate quantification, and suitable inclusion selection) in the analysis of individual fluid inclusions by LA-ICP-MS have made great progress with the introduction of new techniques (i.e., femtosecond laser, cooling LA cell, and near-infrared microscopy).

In the present study, we focus briefly on reviewing the elemental analysis of individual fluid inclusions by LA-ICP-MS, emphasize critical aspects of the technique, address the problems and solutions, illustrate the progress made on recent analytical developments, and summarize future challenges. It will not address the applications of individual fluid inclusions, such as the source and distribution of the ore-forming elements, the source and characteristics of the ore-forming fluid, and establishment of the metallogenic model.

\section{SUCCESS RATE OF ABLATION}

In most deposits, metalliferous ore minerals occur together in not very economical transparent phases, such as gangue mineral quartz. Therefore, the study of ore-forming fluids through fluid inclusions in gangue quartz formed in the same generation with ore minerals has received the most attention. For the fluid inclusion host in quartz, the transient high temperature of nanosecond laser ablation (ns-LA) can cause the quartz to crack. As a result, it is easy to produce uncontrollable mineral debris or particles, known as "catastrophic ablation", and the element concentration cannot be obtained accurately due to the loss of fluid or daughter crystals in the fluid inclusions. In general, the failure rate is $>50 \%$ for the analysis of fluid inclusion by LA-ICP-MS. Therefore, most researchers have focused on how to improve the ablation success rate in individual fluid inclusion analysis by LA-ICP-MS.

Inclusion opening techniques. Optimizing the opening procedure for individual fluid inclusion analysis is beneficial to obtain the complete components information of fluid inclusions, also reduces the surface contamination effects and corrects the contributions from the host mineral. Günther et al. ${ }^{16}$ started a stepwise opening procedure (Fig. 1A-C): each fluid inclusion was first opened with a 4-10 $\mu \mathrm{m}$ hole, and the internal fluid splashed around the ablation pit; after that, the laser beam was increased to $20 \mu \mathrm{m}$ which removed the material deposited around the initial pit; and finally, the entire fluid inclusion was ablated by a slightly larger beam size than for the fluid inclusion.

A stepwise increase of laser beam diameter during fluid inclusion ablation considerably improves the control on the ablation process for quartz-hosted inclusions, thus minimizing inclusion loss due to rupturing. ${ }^{16}$ However, the sample surface contamination is difficult to separate from the inclusion (Fig. $1 \mathrm{~A}-\mathrm{C}$ ), and the signal-to-background ratio (SBR) is too low due 


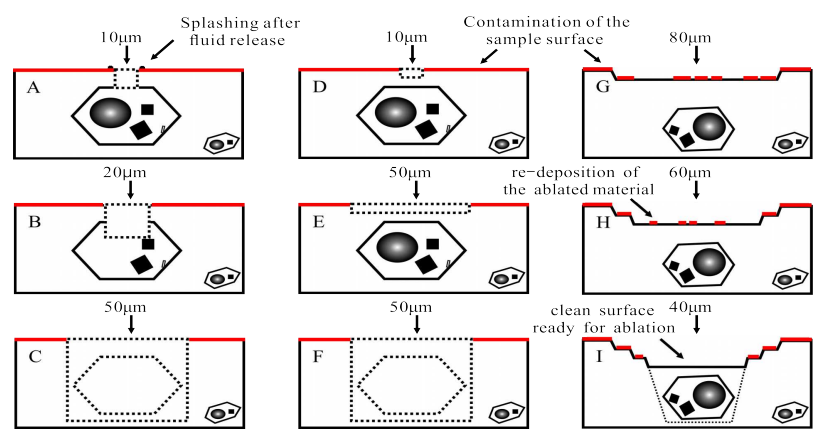

Fig. 1 Typical strategies for opening the fluid individual inclusions: stepwise opening $(\mathrm{A}-\mathrm{C}),{ }^{15}$ straight ablation $(\mathrm{D}-\mathrm{F}),{ }^{21}$ and stepwise pre-ablation $(\mathrm{G}-\mathrm{I}){ }^{24}$

to the long time required for opening the inclusion. ${ }^{10}$ Pettke et $a l^{22}$ developed a straight ablation procedure (Fig. 1D-F). First, the sample surface is ablated by a small aperture diameter (i.e., $10 \mu \mathrm{m}$ ) to reduce the catastrophic ablation before opening the fluid inclusion (Fig. 1D), then straight ablation of fluid inclusions uses a beam size larger than the largest diameter of the inclusion for ablation (Fig. 1E and 1F). The potential for surface contamination is minimized and the SBR for the inclusion signal is maximized, thus achieving lower LODs $(\sim 35 \%))^{10,22}$ When the above straight ablation procedure is used for the analysis of the deep-seated inclusions, signal tailing and element fractionation remains serious. An improved inclusion opening technique called "stepwise pre-ablation cleaning procedure" was developed by Schlöglova et al. ${ }^{27}$ As shown in Fig. 1G-I, the surface contamination ablated from a wider ablation pit; after that the laser could be refocused on the new sample surface and thus reduce the depth of inclusion and the fractionation effect. Due to the multiple ablations required, this method is suitable for minerals that ablate well (e.g., topaz, beryl, garnet). ${ }^{27}$

Cooling laser ablation cell. In the process of laser ablation, the local thermal effect of the ablation point is apt to lead to a sudden increase in internal pressure in the inclusion, which causes the contents in the inclusion to be released in advance and splashed (Fig. 2A). Albrecht et $a .^{28}$ adapted a heating-freezing stage for the ablation cell and performed the ablations at low temperature (e.g. $-40^{\circ} \mathrm{C}$ ). The synthetic $\mathrm{NaCl}-\mathrm{H}_{2} \mathrm{O}$ or $\mathrm{H}_{2} \mathrm{O}-\mathrm{CO}_{2}-\mathrm{NaCl}$ fluid inclusions in quartz can convert into the solid phase (Fig. 2B) and are well-controlled ablations. ${ }^{28}$ This method has been successfully applied to study the high internal pressure $\mathrm{CO}_{2}$-rich fluid inclusions in quartz vein-style Au-Mo deposits. ${ }^{29}$ Recently, a simple and low-cost Peltier cooling LA cell was designed in our laboratory. ${ }^{30}$ Compared to the cryogenically cooled LA cell, it has a faster cooling and heating rate $\left(3 \sim 6^{\circ} \mathrm{C} / \mathrm{min}\right)$

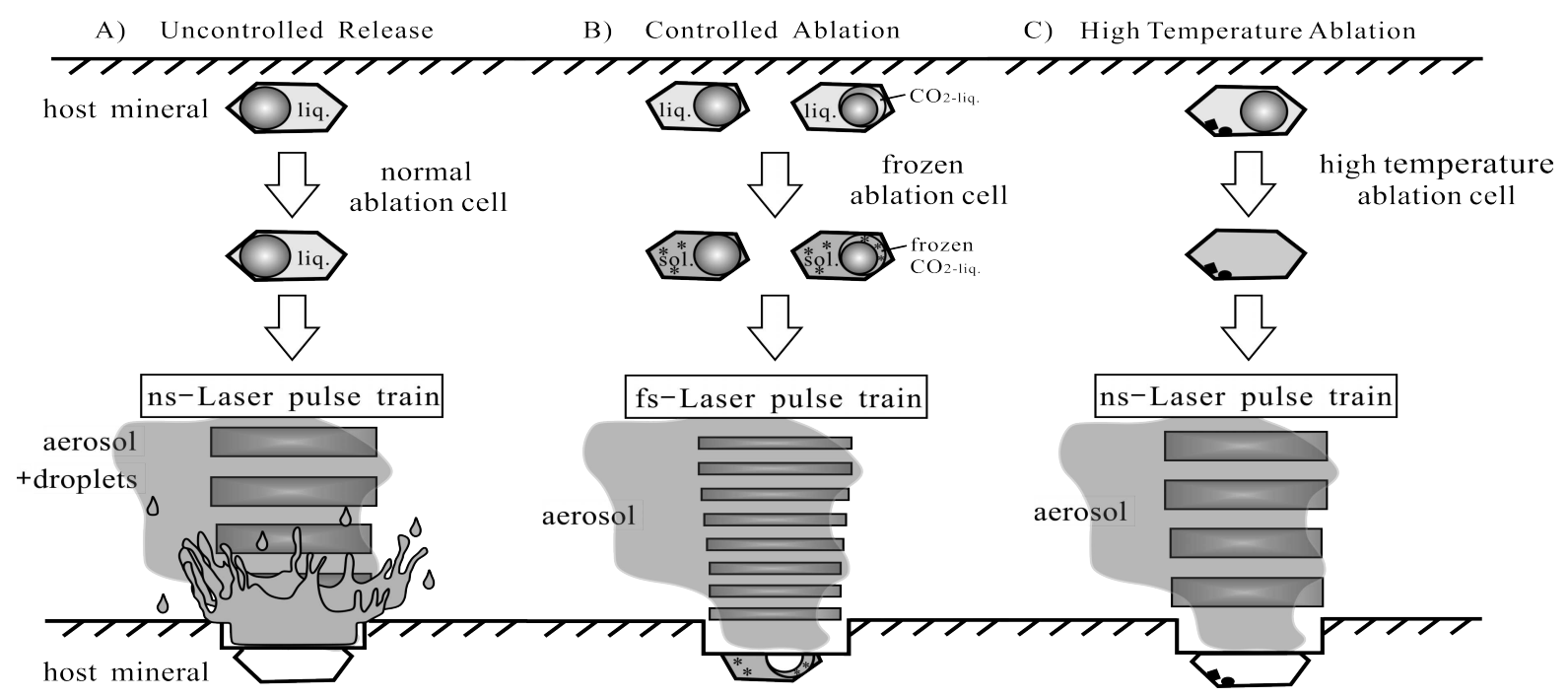

Fig. 2 Simulation diagram of (A) ns-Laser of fluid inclusions at room temperature, (B) fs-Laser of fluid inclusions with the freezing technique, ${ }^{28}$ and (C) ns-Laser of fluid inclusions with the heating technique. ${ }^{30}$ 

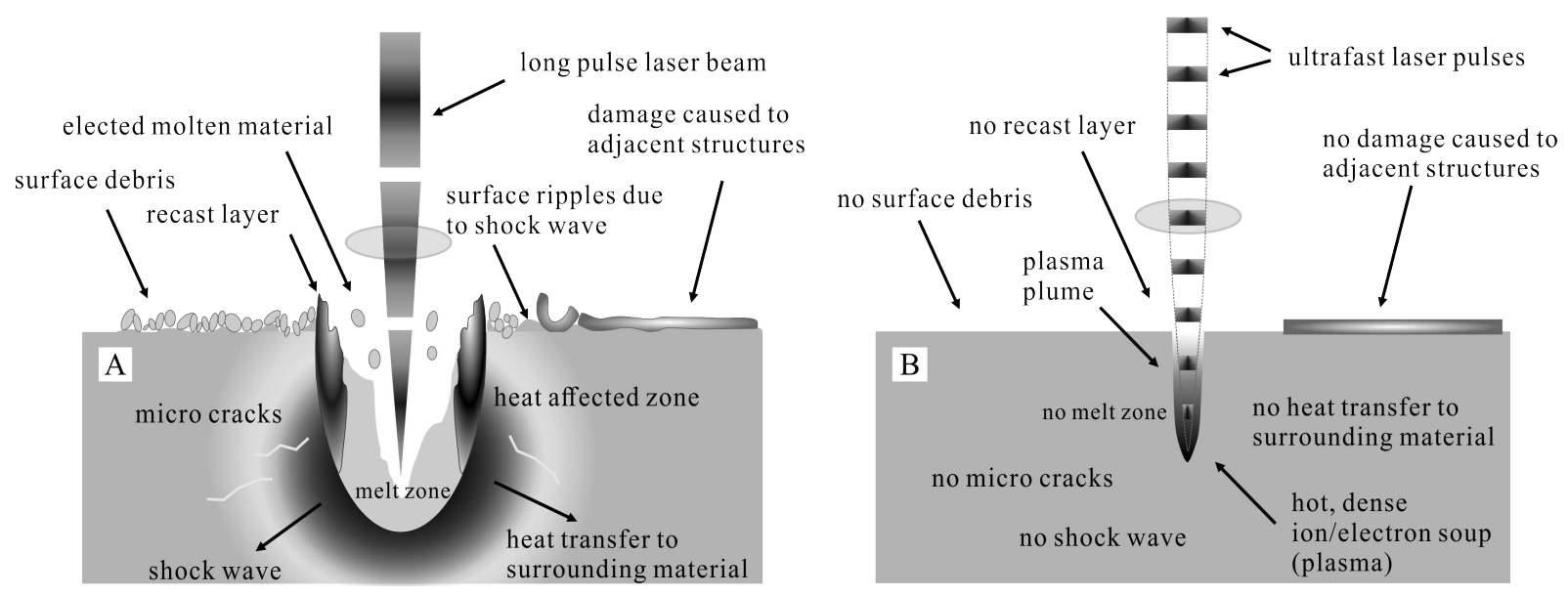

Fig. 3 Laser-matter interaction: (A) nanosecond pulses, and (B) femtosecond pulses. ${ }^{23}$

and more accurate temperature control $\left( \pm 0.5^{\circ} \mathrm{C}\right)$. In addition, a wide temperature range $\left(-35 \sim 180{ }^{\circ} \mathrm{C}\right)$ is predicted in the analysis of low or medium pressure inclusions by convention of the heterogeneous inclusion into the nearly gas-liquid homogeneous inclusion (Fig. 2C).

Application of femtosecond laser. An alternative method used to avoid the catastrophic fluid inclusion crack is the femtosecond laser (fs-LA). On the fs time scale, the laser is predominantly non-thermal, causes less sample damage than longer pulses (ns-LA), provides ultra-fine aerosol particles, and has the potential to eliminate fractionation and matrix effects. ${ }^{23,24}$ Compared with the common nanosecond laser (ns-LA), the greatest advantage of fs-LA is minimal heat transfer from the laser spot into the sample during ablation, ${ }^{31}$ resulting in minimized internal pressure of fluid inclusion (Fig. 3). ${ }^{28}$ Borisova et $a l .{ }^{32}$ used a near infrared (NIR)-fs-LA-QMS system to analyze successfully 32 elements in $\mathrm{NaCl}-\mathrm{HCl}-$ rich fluid inclusions. Albrecht et al. ${ }^{28}$ determined the trace element concentrations in natural fluid inclusions by an ultraviolet (UV)-fs-LA-ICP-MS system with a cryogenically cooled LA cell. A high success rate $(>90 \%)$ was achieved since the fs-laser allows excellent control over the opening procedure of frozen fluid inclusions. ${ }^{28}$ However, Pettke et al. ${ }^{10}$ speculated that, particlularly for fluid inclusion analysis with fs-LA, problems may arise, such as cracking at the crater bottom, associated material loss or phase explosions, and an uncontrolled opening of the inclusion.

\section{ACCURATE QUANTIFICATION}

General procedure. Accurate quantification follows a stepwise procedure and includes: i) a correction for host mineral contributions on background-corrected signal intensities; ii) calculation of apparent element concentrations based on the external standard used; iii) the intermediate results are converted to fluid inclusion element concentrations by using an internal standard (e.g., $\mathrm{Na}, \mathrm{Cl}$, or $\mathrm{K}$ ) from micro-thermometrically determined $\mathrm{NaCl}_{\text {equiv }}$ concentrations corrected for the presence of other major salt cations; iv) each calculated element concentration is compared to its analysis-specific "LOD”. This procedure is described in detail in previous studies. ${ }^{10,20,21,33}$

External and internal standards. Günther et al. ${ }^{16}$ first reported a valid calibration procedure for an external standard combined with an internal standard to achieve fluid inclusion quantification in LA-ICP-MS. In this work, an external standard based on a NIST SRM glass or an aqueous standard solution is ablated directly through a plastic film. A "dual gas flow system" was used for the calibration where the aerosol of the fluid inclusion is mixed with the known multi-element 
standard solution and enters the ICP plasma, then the ratios of $\mathrm{K} / \mathrm{Sr}$ and $\mathrm{Mg} / \mathrm{Sr}$ in the halite fluid inclusion are measured. ${ }^{34}$ The synthetic quartz inclusion based on the silica capillary filled standard solution is also widely used for calibration. ${ }^{35-37}$ Especially for halogens (i.e., Br, $\mathrm{Cl}$, or S), they are low or not present in the NIST SRM glass. The synthetic fluid inclusions of the scapolite mineral sample (Sca17), natural afghanite (AfgAA), and Durango apatite as the external standards successfully measured the $\mathrm{Br}, \mathrm{Cl}$, and $\mathrm{S}$ in high-salinity fluid inclusions. $^{38,39}$ Absolute concentrations of target elements were calculated from the element ratios via an internal standard element $(\mathrm{Na})$, whose concentration was determined by micro-thermometric measurements prior to ablation. ${ }^{16}$ For low-salinity $\mathrm{NaCl}-\mathrm{H}_{2} \mathrm{O}$ systems, the equivalent concentration of the $\mathrm{Na}$ internal standard was calculated by mass-balance approaches or the charge-balance method. ${ }^{20,21}$ Some reports demonstrated that the concentration of the $\mathrm{Na}$ internal standard was calculated by the charge-balance method and a more accurate result was obtained with the $\mathrm{NaCl}-\mathrm{X}_{\mathrm{n}} \mathrm{Cl}-\mathrm{H}_{2} \mathrm{O}$ system, ${ }^{21,40,41}$ such as reducing the relative standard deviation of $\mathrm{Na}$ from $27 \%$ to $16 \%$, but not in other anionic systems. Based on a numerical model of $\mathrm{NaCl}-$ $\mathrm{CaCl}_{2}-\mathrm{H}_{2} \mathrm{O}$ as presented by Steele-MacInnis et al., ${ }^{42}$ the accurate determination of $\mathrm{Na}$ internal standard for fluid inclusions in Ca-rich systems was achieved, such as for rich divalent ions (e.g., $\mathrm{Mg}$ and $\mathrm{Ca}$ ) and more complex systems (e.g., $\mathrm{K}, \mathrm{Ca}, \mathrm{Mg}$, and $\mathrm{Fe}$ ). ${ }^{7,43-47}$

Data acquisition. Laser ablation of an individual fluid inclusion, even when carried out ideally, produces transient signals of limited duration, which may vary unevenly over several orders of magnitude during a signal duration of typically 5-40 s, or, for elements concentrated in tiny daughter crystals, possibly even during much shorter intervals. Besides, almost all natural fluid inclusions are small in size (i.e., $5-20 \mu \mathrm{m}$ ) and low in element concentration. Therefore, fast acquisition of the transient signals by highly sensitivity mass spectrometry is crucial to obtain information that is more elemental.

Three configurations of mass spectrometers, quadrupole mass spectrometer (QMS), sector -field mass spectrometer (SFMS), and time-of-flight mass spectrometer (TOFMS), are commonly used for data collection. The anlaytical performance of these three mass spectrometers for the multi-element analysis in natural fluid inclusions were compared by Harlaux et $a l^{48}$ Their results indicate that the cycle time of $273 \mathrm{~ms}$ (QMS), $560 \mathrm{~ms}$ (SFMS), and $30 \mathrm{~ms}$ (TOFMS) can obtain 10,5 , and 100 data points, respectively, if the signal duration is about $3 \mathrm{~s}$. The more data points collected, the more favorable instantaneous signal integration, and the better analytical precision be obtained. However, the sensitivity of TOFMS, which has quasi-simultaneous data acquisition for all isotopes, is lower than that of QMS and SFMS. The sensitivity of SFMS is highest, has the advantage of low detection limits, but the longer acquisition time limits the number of measurable elements $(<5)$ and the obtainable precision. As for QMS, it has good reproducibility, precision, and accuracy, but is limited by relatively high detection limits, needs a compromise between signal duration and cycle time, and the measurable elements generally are less than $20 .^{48,49} \mathrm{~A}$ "jump routine" was developed to optimize QMS data acquisition, that is, a different dwell time for different elements (such as $10 \mathrm{~ms}$ for low concentration elements and $2 \mathrm{~ms}$ for high concentration elements which can reduce the total time of single analysis), which ensures precision and improves the detection limits simultaneously. ${ }^{22}$ Despite the high sensitivity of SFMS and the rapid analysis of TOFMS, QMS is still the most commonly used instrument in the world because of its low cost, simplicity of operation, and higher stability. ${ }^{10}$

\section{SUITABLE INCLUSION SELECTION}

Selection of fluid inclusions. Although fluid inclusions are present in almost all minerals, the selection of an ideal fluid inclusion material likely accounts for $>50 \%$ 
of the success of a LA-ICP-MS fluid inclusion investigation. ${ }^{10}$ The following guidelines may be helpful.

i) Optimum inclusion size is between 10 and $40 \mu \mathrm{m} .^{10}$ Larger inclusions are often rather difficult to analyze at controlled ablation conditions due to more frequent quartz breakout at larger LA beam sizes. ${ }^{22,50}$

ii) Depth inclusion should be located $20-50 \mu \mathrm{m}$ below the surface (which is less than the diameter of the inclusion, e.g., $20 \mu \mathrm{m}$ for $10 \mu \mathrm{m}$ sized inclusion and 50 $\mu \mathrm{m}$ for $40 \mu \mathrm{m}$ sized inclusion) to minimize surface contamination, signal tail, and the effect of elemental fractionation. ${ }^{51}$ Therefore, the aspect ratio of ablation depth to laser beam diameter should be limited to $<2$. $^{52}$

iii) Spatial isolation of individual inclusion is required to avoid being released adjacent to the inclusions. ${ }^{22}$ Fluid inclusion assemblages are the perfect choice to improve the representativeness of LA-ICP-MS analysis data.

iv) Optimum fluid inclusions are spherical, given that cylindrical inclusions at optimal orientation do not exist. Such inclusions provide the largest possible mass of material available per unit time and achieve maximum signal-to-background ratios and the best detection limit. ${ }^{10}$

v) Fluid inclusion host minerals need to be of high strength, reducing fluid leakage during laser ablation. ${ }^{50}$ The amount of ablated solutes is largely controlled by the host mineral ablation rates; high-density inclusions return higher sensitivities and thus lower LODs. For example, a $30 \mu \mathrm{m}$ vapor inclusion (e.g., $0.1 \mathrm{~g} \mathrm{~cm}^{-3}$ density) has one order of magnitude less solutes by mass than a high density inclusion of the same size $\left(1.0 \mathrm{~g} \mathrm{~cm}^{-3}\right) .{ }^{10,22}$

Quartz-hosted fluid inclusion. A key source for information on the physical and chemical conditions of hydrothermal ore formation has been fluid inclusion trapped during mineral growth. ${ }^{53}$ Interpretation of the P-T-X conditions of ore deposition then assumes that the information obtained from gangue minerals is applicable to ore minerals. ${ }^{18}$ Quartz is known as one of the purest minerals in the world. The study of ore-forming fluids through fluid inclusions in gangue quartz formed in the same generation with ore minerals is a best means. Audétat et al. ${ }^{18}$ selected a quartz crystal from the Yankee Lode tin deposit with fluid inclusions of different generations and analyzed it by LA-ICP-MS. The changes of element concentration and capture temperature revealed the physical and chemical mechanism of ore precipitation in the early, middle, and late stages. This study shows that the major and minor element concentrations are high and independent of fluctuations in temperature and pressure in the early fluid inclusions. This corresponds to the early stage of fluid evolution, then drops over several orders of magnitude in later inclusions, and reflects a dilution of numerous meteoric water. ${ }^{18}$ Since Audétat et al. reported this research in the journal of Science, quartz-hosted fluid inclusions have been studied widely and applied to ore deposits, such as the source of ore-forming elements, ${ }^{23,55}$ the distribution of elements in different phases, ${ }^{19,50}$ the ore-forming fluid characteristics, ${ }^{3,56}$ and the source of ore-forming fluid. ${ }^{36,39}$ Although the quartz fluid inclusion easily cracks during the LA process, it remains an ideal host for most fluid inclusion studies because of its unique advantages (i.e., transparent and easy to observe, less abundant ore-forming impurities, and wide distribution) compared to ore minerals.

\section{Semitransparent ore mineral-hosted fluid inclusion.}

Nowadays, more and more researchers have challenged the assumption of the close spatial association of gangue (i.e., quartz) and ore minerals alone, even when their contemporaneous deposition cannot be demonstrated by unambiguous textural evidence. ${ }^{3-5}$ The composition of fluid inclusions in gangue minerals and ore minerals would be different only in exceptional cases. ${ }^{57}$ Therefore, the ore minerals precipitated by crystallization of fluids could more directly restore the characteristics of ore-forming fluids. ${ }^{18}$ Compared with some opaque minerals, the semitransparent ore minerals were given 
priority because with the LA standard configuration visible light microscope it is easier to observe the fluid inclusions. Some semitransparent ore minerals, such as sphalerite $^{3}$ and cassiterite, ${ }^{58}$ have been successfully applied without the catastrophic ablation. One crucial and necessary attention is background correction in data reduction because the ore mineral contains abundant ore-forming elements (targets in fluid inclusion). Wilkinson et $a l^{3}$ analyzed sphalerite-hosted fluid inclusions from the Mississippi Valley-type zinc-lead deposit and deducted the contributions of the host mineral (sphalerite) using the following equation:

$$
I_{F I}^{a}=I_{m i x}^{a}-I_{m i x}^{i} \cdot \frac{I_{m i n}^{a}}{I_{m i n}^{i}}
$$

Where $I$ is the net analyte signal (in counts per second), the subscripts FI, mix, and min refer to the pure inclusion signal, the mixture of inclusions and host signal, the mineral only signal, and the superscript a is the analyte element, $i$ an element dominantly present in the host mineral (such as $\mathrm{Zn}$ in sphalerite). ${ }^{3}$

Opaque ore mineral-hosted fluid inclusions. It is almost impossible to analyze the fluid inclusions hosted by opaque ore minerals by LA-ICP-MS equipped with a visible light microscope. Fortunately, the infrared-light microscopy technique fills in the gap and has been used for observation and localization of fluid inclusions in ore minerals, where the fractures, cleavages, or ablation craters can be marked to facilitate laser ablation. ${ }^{4}$ In 2010 , Kouzmanov et $a l .{ }^{57}$ first combined a near-infrared microscope with LA-ICP-MS for analysis of fluid inclusion assemblages hosted by pyrite, enargite, and quartz, which are used to trace the source and evolution of the fluids in high-sulfidation epithermal veins overprinting a porphyry copper deposit. However, the thermal effect of the NIR light on ore minerals affects the NIR transparency of minerals directly, like the NIR transparency of pyrite, wolframite, stibnite, and enargite which decreases as temperature increases. ${ }^{4}$ Recently,
Casanova et al. ${ }^{5}$ reduced the thickness of the sample to increase the mineral transmittance, though it reduced the number of inclusions preserved for micro-thermometry. Besides, the trace element concentration, mineral habitus, and physical properties are other limiting factors of minerals for NIR transmittance. ${ }^{4,58}$

\section{SUMMARY AND PROSPECT}

In summary, the LA-ICP-MS in-situ analysis of individual fluid inclusions has made a breakthrough by improving the success rate of ablation by optimization of the opening procedure, introduction of the cooling ablation cell, and use of the fs-laser. The NIST SRM glass or synthetic inclusion was applied as an external standard to obtain an element concentration ratio, and then absolute concentration was calculated from the element ratios via an internal standard element whose concentration was determined by micro-thermometric measurements.

Although the refined LA-ICP-MS method is widely used for the elemental analysis of individual fluid inclusions, we currently identified three major areas where significant progress in the LA-ICP-MS analysis of fluid inclusions has been achieved.

i) Method development for element determination in non-transparent ore mineral-hosted fluid inclusions. For a long time, one of the questions still under debate in fluid inclusion research conducted on hydrothermal ore deposits is the following: ${ }^{59-61}$ Do the fluids in cogenetic gangue minerals (i.e., quartz) represent the ore-forming fluids, and is the chemical composition of fluid inclusions hosted in cogenetic gangue and ore minerals the same? Recently, Kouzmanov et al. ${ }^{57}$ developed a NIR petrography microscope LA-ICP-MS method to compare the major and trace element concentrations of fluid inclusion assemblages hosted by pyrite, enargite, and quartz. The findings showed that the fluids trapped in cogenetic quartz and ore minerals are chemically distinct. 
Therefore, method development of metals in opaque ore-hosted fluid inclusions by LA-ICP-MS with a near-infrared (NIR) light microscope is imperative. Two crucial problems should be considered: a) Improvement of the NIR transparency because it is dependent on many factors, such as mineral temperature, ${ }^{5}$ trace element concentration in the mineral, mineral habitus, and physical properties. ${ }^{4,58}$ b) Establishment of an effective background correction method to alleviate the concentrations of abundant ore-forming elements on the target elements in fluid inclusions.

ii) Improvement of detection limit. Most natural individual fluid inclusions are small in size $(<20 \mu \mathrm{m})$, less in analytical materials ( $\mathrm{pL}$ to $\mathrm{nL}$ ), and there is a dilution effect in the aerosol transport process, resulting in problems such as high detection limits of trace elements, weak instantaneous signal of the mass spectrometer, and large error in analytical results. For instance, the detection limit of the metal elements is generally $10 \sim 100 \mu \mathrm{g} \mathrm{g}^{-1}$, while that of some nonmetals is as high as $500 \mu \mathrm{g} \mathrm{g}^{-1}$, or more. Becuase halogens have high ionization energies and high detection limit, it is difficult to detect low concentrations of halogens, but $\mathrm{Br}$, $\mathrm{Cl}$, or $\mathrm{Br} / \mathrm{Cl}$ are one of the important indexes to trace the source of ore-forming fluids.$^{36,39,62,63}$ Several possible ways can be used to improve the SBR: (a) Developing high sensitivity mass spectrometry; (b) Increasing the extraction efficiency of laser ablation aerosol by use of the small volume ablation cell, the double chamber ablation cell, or the local aerosol extraction ablation cell ${ }^{64-66}$ (c) Improving the ionization efficiency of ICP by addition of a small amount of gas with high thermal conductivity (i.e., $\mathrm{H}_{2}$ or $\mathrm{N}_{2}$ ). ${ }^{10,22,67}$

iii) Accurate determination of internal standard concentration. The largest source of error for quantitative calibrations is the absolutely necessary internal standard constraint ${ }^{22}$ however, it can only be obtained by the calculation of empirical formula. We developed a valid method for the simultaneous determination of 43 elements in dissolved solution of oceanic polymetallic nodules. ${ }^{68}$ It is based on sharing one ICP, detecting trace elements by MS, and measuring the major and minor elements by OES. This strategy has potential to be used in fluid inclusion analysis: the laser-generated fluid inclusion aerosol is split into two transport tubes via a Y-shaped connector and simultaneously introduced into ICP-MS and ICP-OES. The target elements were measured on the ICP-MS instrument, while the internal standard elements were determined using the ICP-OES.

iv) Development of well-determined calibration materials and/or fluid inclusion certified reference materials (CRMs).

\section{AUTHOR INFORMATION}

\section{Corresponding Author}

"W. Guo.

Email address: Wei.Guo@cug.edu.cn.

\section{Notes}

The authors declare no competing financial interest.

\section{ACKNOWLEDGMENT}

This work was supported by the National Key Research and Development Program of China (No. 2016YFE0203000), the National Natural Science Foundation of China (No. 41873072), and the Fundamental Research Funds for the Central Universities, China University of Geosciences (Wuhan).

\section{REFERENCES}

1 H. Z. Lu, H. R. Fan, P. Ni, G. X. Ou, K. Shen and W. H., Fluid Inclusion. Beijing: Science Press: 2004.

2 J. J. Wilkinson, Lithos, 2001, 55, 229-272.

3 J. J. Wilkinson, B. Stoffell, C. C. Wilkinson, T. E. Jeffries, and M. S. Appold, Science, 2009, 323, 764-767.

4 M. Ortelli, K. Kouzmanov, M. Walle, N. Ubrig and V. Casanova, Econ. Geol., 2018, 113, 1845-1860.

5 V. Casanova, K. Kouzmanov, A. Audétat, M. Walle, N. Ubrig, M. Ortelli and L. Fontbote, L., Econ. Geo., 2018, 
113, 1861-1883.

6 J. Y. Pan, P. Ni and R. C. Wang, Am. Mineral., 2019, 104, 1092-1116.

7 G. X. Chi, H. X. Chu, D. Petts, E. Potter, S. Jackson and A. Williams-Jones, Sci. Rep., 2019, DOI: 10.1038/s41598-019-42032-0.

8 G. K. Czamanske, E. Roedder and F. C. Burns, Science, 1963, 140, 401-403.

9 C. A. Heinrich, J. H. C. Bain, J. J. Fardy, J. J. and C. L. Waring, Geochim. Cosmochim. Acta, 1994, 57, 2991-3000.

10 T. Pettke, F. Oberli, A. Audétat, M. Guillong, A. C. Simon, J. J. Hanley and L. M. Klemm, Ore Geol. Rev., 2012, 44, $10-38$.

11 A. L. Gray, Analyst., 1985, 110, 551-556.

12 S. H. Hu, Z. C. Hu, Y. S. Liu, Y. Luo, S. L. Lin and S. Gao, Front. Earth Sci-PRC, 2001, 8, 434-440.

13 Y. T. Li, W. Guo, Z. C. Hu, L. L. Jin, S. H. Hu and Q. H. Guo, J. Agric. Food Chem., 2019, 67, 935-942.

14 T. G. Lan, R. Z. Hu, H. R. Fan, X. W. Bi, Y. W. Tang, W. Mao and Y. H. Chen, Acta. Petrol. Sin, 2017, 33, 3239-3262.

15 D. Günther and B. Hattendorf, TRAC-Trend. Anal. Chem., 2005, 24, 255-265.

16 D. Günther, A. Audétat, R. Frischknecht and C. A. Heinrich, J. Anal. At. Spectrom., 1998, 13, 263-270.

17 D. Günther, R. Frischknecht, H. J. Muschenborn and C. A. Heinrich, Fresen. J. Anal. Chem., 1997, 359, 390-393.

18 A. Audétat, D. Günther and C. A. Heinrich, Science., 1998, 279, 2091-2094.

19 C. A. Heinrich, D. Günther, T. A. Audétat, T. Ulrich and R. Rrischknecht, Geology, 1999, 27, 755-758.

20 C. A. Heinrich, T. Pettke, W. E. Halter, M. Aigner-Torres, A. Audétat, D. Günther, B. Hattendorf, D. Bleiner, M. Guillong and I. Horn, Geochim. Cosmochim. Acta, 2003, 67, 3473-3497.

21 M. M. Allan, B. W. D. Yardley, L. J. Forbes, K. I. Shmulovich, D. A. Banks and T. J. Shepherd, Am. Mineral., 2005, 90, 1767-1775.

22 T. Pettke, Mineralogical Association on Canada, 2008, 40, 189-217.

23 B. Fernández, F. Claverie, C. Pecheyran and O. F. Donard, TRAC-Trend. Anal. Chem., 2007, 26, 951-966.

24 C. C. Wohlgemuth-Ueberwasser and K. P. Jochumb, J. Anal. At. Spectrom., 2015, 30, 2469-2480.

25 C. Liu, X. L. Mao, S. S. Mao, X. Zeng, R. Greif and R. E. Russo, Anal. Chem., 2004, 76, 379-383.
26 M. Ohata, D. Tabersky, R. Glaus, J. Koch, B. Hattendorf and

D. Günther, J. Anal. At. Spectrom., 2014, 29, 1345-1353.

27 K. Schloglova, M. Walle and C. A. Heinrich, J. Anal. At. Spectrom., 2017, 32, 1052-1063.

28 M. Albrecht, I. T. Derrey, I. Horn, S. Schuth and S. Weyer, $J$ . Anal. At. Spectrom., 2014, 29, 1034-1041.

29 W. Jian, M. Albrecht, B. Lehmann, J. Mao, I. Horn, Y. Li, H . Ye, Z. Li, G. Fang and Y. Xue, Geofluids., 2018, DOI: $10.1155 / 2018 / 3692180$.

30 W. Guo, X. Lin and S. H. Hu, J. Earth Sci., 2019, DOI: 10. 3799/dqkx.2019.199.

31 P. Pronko, S. Dutta, D. Du and R. Singh, J. Appl. Phys., 1995, 78, 6233-6240.

32 A. Borisova, R. Thomas, S. Salvi, F. Candaudap, A. Lanzanova and J. Chmeleff, Mineral. Mag., 2012, 76, 91 -113 .

33 R. J. Bodnar, Geochim. Cosmochim. Acta, 1993, 57 , 683-684.

34 T. J. Shepherd, S. R. Chenery, Geochim. Cosmochim. Acta, 1995, 59, 3997-4007.

35 A. M. Ghazi and S. Shuttleworth, Analyst., 2000, 125, 205-210.

36 B. Stoffell, M. S. Appold, J. J. Wilkinson, N. A. McClean and T. E. Jeffries, Econ. Geol., 2008, 103, 1411-1435.

37 S. H. Sun, M. Y. Hu, C. L. Liu, P. C. Jiao, L. C. Ma, X. Wang and X. C. Zhan, Chin. J. Anal. Chem., 2013, 41, 235241.

38 J. H. Seo, M. Guillong, M. Aerts, Z. Zajacz and C. A. Heinrich, Chem. Geol., 2011, 284, 35-44.

39 T. Fusswinkel, C. Giehl, O. Beermann, J. R. Fredriksson, D. Garbe-Schoenberg, L. Scholten and T. Wagner, J. Anal. At. Spectrom., 2018, 33, 768-783.

40 T. Wagner, T. Fusswinkel, M. Walle and C. A. Heinrich, Elements, 2016, 12, 323-328.

41 T. G. Lan, R. Z. Hu, H. R. Fan, X. W. Bi, Y. W. Tang, L. Zhou, W. Mao and Y. H. Chen, Acta Petrol. Sin., 2017, 33, 3239-3262.

42 M. Steele-MacInnis, R. J. Bodnar and J. Naden, Geochim. Cosmochim. Acta, 2011, 75, 21-40.

43 M. Leisen, J. Dubessy, M. C. Boiron and P. Lach, Geochim. Cosmochim. Acta, 2012, 90, 110-125.

44 T. U. Schlegel, M. Waelle, M. Steele-MacInnis and C. A. Heinrich, Chem. Geol, 2012, 334, 144-153.

45 M. Steele-MacInnis, J. Ridley, P. Lecumberri-Santhez, T. U. Schlegel and C. A. Heinrich, Earth-Sci. Rev., 2016, 159, 14 -35 . 
46 C. Y. Li, Y. H. Jiang, Y. Zhao, C. C. Zhang, M. Ling, X. Ding, H. Zhang and J. Li, Solid Earth Sciences, 2018, 3, 8-15.

47 M. Leisen, M. C. Boiron, A. Richard and J. Dubessy, Chem. Geol., 2012, 330, 197-206.

48 M. Harlaux, O. Borovinskaya, D. A. Frick, D. Tabersky, S. Gschwind, A. Richard, D. Günther and J. Mercadier, J. Anal. At. Spectrom., 2015, 30, 1945-1969.

49 M. Waell and C. A. Heinrich, J. Anal. At. Spectrom., 2014, 29, 1052-1057.

50 K. Schloglova, M. Walle, C. A. Heinrich and D. Dolejs, Mineral Resources to Discover, 2017, 1-4, 95-98.

51 M. Guillong, T. Pettke and L. Danyushevsky, Abstract. Goldschmidt 2011 Conference, Prague. August 14-19.

52 M. Guillong and T. Pettke, J. Anal. At. Spectrom., 2012, 27, 505-508.

53 E. Roedder, Mineralogical Society of America, 1984, 12, 664.

54 H. Liu, X. Bi, H. Lu, R. Hu, T. Lan, X. Wang, M. Huang, B. Yu, Q. Zeng, H. E. Frimmel, Y. Wang, W. Guo, G. Sun, T. Zhou and J. Li, J. Asian Earth Sci., 2018, 161, 35-56.

55 A. R. Campbell and K. S. Panter, Geochim. Cosmochim. Acta, 1990, 54, 673-681.

56 P. Chen, Q. Zeng, T. Zhou, Y. Wang, B. Yu and J. Chen, Ore Geol. Rev., 2019, 104, 26-45.
57 K. Kouzmanov, T. Pettke and C. A. Heinrich, Econ. Geol., 2010, 105, 351-373.

58 V. Luders, Miner. Depos., 2017, 52, 663-673.

59 L. Bailly, L. Grancea and K. Kouzmanov, Econ. Geol., 2002, 97, 415-423.

60 T. Shimizu, M. Aoki and T. Kabashima, Resour. Geol., 2003, 53, 115-126.

61 S. G. Hagemann and V. Lüders, Miner. Deposita, 2003, 38, 936-952.

62 J. H. Seo and Z. Zajacz, Geochim. Cosmochim. Acta, 2016, 183, 125-137.

63 G. Tuba, D. J. Kontak, Z. Zajacz and J. A. Petrus, Chem. Geol., 2019, DOI: 10.1016/j.chemgeo.2019.119326.

64 Y. S. Liu, Z. C. Hu, H. L. Yuan, S. H. Hu and H. H. Cheng, J. Anal. At. Spectrom., 2007, 22, 582-585.

65 Z. C. Hu, Y. S. Liu, S. Gao, S. H. Hu, R. Dietiker and D. Günther, J. Anal. At. Spectrom., 2008, 23, 1192-1203

66 H. Lindner, D. Autrique, J. Pisonero, D. Günther and A. Bogaerts, J. Anal. At. Spectrom., 2010, 25, 295-304.

67 M. Guillong and C. A. Heinrich, J. Anal. At. Spectrom., 2007, 22, 1488-1494.

68 S. H. Hu, X. J. Wang, W. Ge, A. R. Li, L. L. Jin and X. H. Wang, Chin. J. Anal. Chem., 2004, 9, 1139-1144. 